\title{
OIL \& GAS INDUSTRY IN BRAZIL: A BRIEF HISTORY AND LEGAL FRAMEWORK
}

Laís Palazzo Almada

Regulation Specialist at the Agência Nacional de Petróleo, Gás Natural e Biocombustíveis - Brazil. Master Candidate at The University of Oklahoma College of Law. Master Candidate at University of Sao Paulo.

Virgínia Parente

Professor at the Energy Program, University of Sao Paulo (IEE/ USP). Ph.D. in Finance and Economics, Energy Specialist.

\begin{abstract}
The recently announced discovery of potential large-scale reserves in the Brazilian so called pre-salt layer has resulted in a new legal framework for the country. In this new architecture, old and new regulation share the legal arena. Exploring this context, this paper provides an overview of the emergence and evolution of the oil and gas market in Brazil, and discusses the new legal configuration where the prevailing Concession System co-exists with the Production Sharing System and the Onerous Assignment. The conclusion pinpoints the challenges that the country faces in dealing with two energy sources -oil and gas - that will play an increasing role in Brazil's future. It also indicates that the introduction of competition also has brought new features and improvements to oil and gas industry in Brazil. Structuring a robust legal framework that will foster the necessary investments is not only a challenge for the Brazilian economy, but also one that has to be tackled by many emergent economies with newly hydrocarbon discoveries.
\end{abstract}

Keywords: Oil\&Gas - Brazilian Regulation - Pre-salt.

\section{INTRODUCTION}

Oil and gas continue to be an important source of energy all over the world. Although many investments have been made in new technologies to aid in developing new energy sources, including renewable ones, the world will still depend on oil and gas for many years (IEA, 2012).

Several factors have caused changes in many Latin American markets, especially economic and political factors; among the most important are a rise in the international price of fossil fuels, including oil 
and gas, and the importance of energy security (BRAGA and CAMPOS, 2012). In Brazil, the recently announced discovery of potential largescale reserves has trigged intense debate and resulted in a new legal framework (IBP, 2013).

In 2012, the Brazilian Congress passed three new laws concerning Oil and Gas: (i) Law 12,276/2010 (Onerous Assignment); (ii) Law 12,304/2010 (PPSA -Pré-sal Petróleo S.A. [Pre-Salt Petroleum Co.]); and (iii) Law 12,351/2010 (Production Sharing system). In addition, the Petroleum law - Law 9,478/1997, from 1997, which regulates the Concession system - is still existing discovery of potential large-scale reserves in the Brazilian so called pre-salt layer revenue sharing scheme for Brazilian oil and gas.

This paper aims to provide an overview of the emergence and evolution of the oil market in Brazil, focusing on how oil and gas regulation has been organized in the country. It also analyses the role of International Oil Companies in the Brazilian recent oil and gas history. The so-called Regulatory Mixed Regime as well as some relevant facts which were controversial during some bidding rounds will also be explained within the scope of the Concession Model, established by Law 9,478/1997. This review is based mainly on a regulatory and legal approach of the oil and gas framework released by Brazilian regulatory authority, from 1997 to 2012, and the latest version of the country's Constitution of 1988 and its amendments.

This paper aims to provide an overview of the emergence and evolution of the oil market in Brazil. It also focuses on the role of International Oil Companies as well as the Brazilian oil and gas history. The so-called mixed regime will be explained, as will the importance of the Concession Model, established by Law 9,478/1997. Some relevant facts which were controversial during some Bidding Rounds will also be explained.

This paper is divided in five parts. The first part will describe the establishment of Petrobras, Brazilian National Oil Company and the legal history of oil and gas monopoly in the country, including a consideration of the relevant legal and constitutional provisions.

Part two briefly analyzes the legal framework, focusing on the Petroleum Law, which established the ANP -Agência Nacional de Petróleo, Gás Natural e Biocombustíveis [National Regulatory Agency of Petroleum, Natural Gas and Biofuel] — and instituted the Concession regime.

In sequence, the three laws that enacted the mixed regime, in 2010, will be addressed. Part three discusses the Production Sharing System and the Unitization in Brazil, both regulated by Law 12,351/201.

Legal aspects and contractual features of the Onerous Assignment, Law 12,276/2010, are treated in the fourth part of this 
paper. This Assignment allowed Brazilian Government to keep its position as a main shareholder in the world largest capitalization, when Petrobras raised $\mathrm{R} \$ 120.2$ billion (proximately 60.1 billion dollars) (Petrobras, 2010).

Finally, part five discusses the current Brazilian scenario, developed under Concession Model, with some aspects of its Bidding Rounds explained in detail. Some information about production, Operators, Government Takes and the oil and gas market in Brazil will also be considered .

The paper concludes by summarizing with the challenges that the country faces in the important field of oil and gas industry.

\section{PETROBRAS ESTABLISHMENT AND THE OIL MONOPOLY}

Petrobras -Petróleo Brasileiro S.A. [Brazilian Petroleum Co.]was established by the Law 2,004/1953 as the Brazilian state-controlled oil and gas company. Under this law, Petrobras was given a monopoly on oil and gas exploration and production activities (BRAZIL, 1953).

But, as ROSADO, apud BRAGA and CAMPOS (2012), stated, in the 1970's, Petrobras was allowed to enter into risk services contracts with private international oil companies - IOCs, showing a small market opening.

After the oil crisis in 1973, Brazilian President, Mr. Geisel, authorized Petrobras to enter into risk contracts with International Oil Companies-IOCs. At the same time, the President noted that such permission did not mean that the monopoly was no longer enforceable, nor did it mean that the monopoly no longer existed (Estado de São Paulo, 1975).

The fact is that, prior to the Constitution of 1988, Brazil's oil and gas industry was formed not only by Petrobras, but also by other international oil companies that had begun oil exploration in Brazil. Many companies operated in Brazil during this time, including Shell, Exxon, Texaco, BP, ELF, Total, Marathon, Conoco, Hispanoil, Pecten, and Pennzoil. Some National enterprises also participated in these activities: Paulipetro, Azevedo Travassos, and Camargo Corrêa, among others (LUCCHESI, 1998).

On the other hand, in 1972, Petrobras also established an affiliate -Petrobras Internacional S.A. (Braspetro) [Petrobras International Co.] - to act in other countries, at a time when many IOCs were moving toward global integration. During this period, Braspetro discovered oil in a huge field in Iraq (PEDROSO, JR. 2009).

Since the passage of the Constitution of 1967, the oil monopoly has had constitutional status. However, the 1967 Constitution did not mention how this monopoly should be exercised, but set forth the sole 
requirement that it must be done so pursuant to the law. Only in 1988 did the Constitution include more restrictive provisions. In its original version, the Constitution of 1988 had established not only the monopoly, but also the prohibition on contracting with other companies (BRAZIL, 1998).

The Brazilian Constitution considers oil and gas, whether under production or not, property of Federal Union, even though it grants the land owner a participation in production. Article 176 of the Constitution designs the oil and gas treatment, as follows:

"Article. 176. The oilfields whether in production or not, and other mineral resources and potential hydropower constitute distinct property of the soil, for the purpose of exploration or exploitation, and belong to the Union, with a guarantee to the concessionaire of title to the production. \$1- The exploration and mining of mineral resources and the utilization of the potentials referred to by the "caput" of this article may only be performed upon authorization or concession of the Union, in the national interest, by Brazilians or Brazil's national capital, in the form of the law, which shall establish the specific conditions when these activities develop in border strip or indigenous lands. \$2- The owner of the land is ensured participation in the mining proceeds in the form and value as established by law. §3- The authorization for exploration will always be for a fixed period, and the authorizations and concessions provided for in this article may not be assigned or transferred, in whole or in part, without prior consent of the licensor. \$4- The use of the potential of renewable energy of reduced capacity will not depend on the authorization."

1 Art. 176. As jazidas, em lavra ou não, e demais recursos minerais e os potenciais de energia hidráulica constituem propriedade distinta da do solo, para efeito de exploração ou aproveitamento, e pertencem à União, garantida ao concessionário a propriedade do produto da lavra. $\S 1^{\circ}$ A pesquisa e a lavra de recursos minerais e o aproveitamento dos potenciais a que se refere o "caput" deste artigo somente poderão ser efetuados mediante autorização ou concessão da União, no interesse nacional, por brasileiros ou empresa constituída sob as leis brasileiras e que tenha sua sede e administração no País, na forma da lei, que estabelecerá as condições específicas quando essas atividades se desenvolverem em faixa de fronteira ou terras indígenas. $\S 2^{\circ} \mathrm{E}$ assegurada participação ao proprietário do solo nos resultados da lavra, na forma e no valor que dispuser a lei. $\S 3^{\circ}$ - A autorização de pesquisa será sempre por prazo determinado, e as autorizações e concessões previstas neste artigo não poderão ser cedidas 
Further, in Article 177, 1988's Constitution included the exploration of oil, gas, and other hydrocarbons fluids under the Union's monopoly; prohibiting International Oil Companies to act in Brazil (BRAZIL, 1988).

These provisions were amended to maintain the Union's monopoly over oil and gas, but, at the same time, to allow International Oil Companies to act in Brazil. According to the Constitutional Amendment 9, from 1995, the Federal Union may contract the exploration and mining of oil and natural gas and other hydrocarbon fluids (BRAZIL, 1995). The table below shows the 1988version of Constitution and the text adopted since $1995^{2}$.

\begin{tabular}{|c|c|}
\hline Original Version & After Amendment 9 of 1995 \\
\hline $\begin{array}{l}\text { Article. } 177 \text {. The Union's monopoly: } \\
\text { I- The exploration and mining of depo- } \\
\text { sits of oil and natural gas and other hy- } \\
\text { drocarbon fluids; . . } \$ 1 \text { The monopoly } \\
\text { referred to in this article includes the ris- } \\
\text { ks and results arising from the activities } \\
\text { mentioned therein, being forbidden the } \\
\text { Union transferring or granting any kind } \\
\text { of participation, in kind or in value, the } \\
\text { exploitation of oil or natural gas depo- } \\
\text { sits, except as provided in art. } 20, \S 1 \text {. }\end{array}$ & $\begin{array}{l}\text { Article. 177. The Union's monopoly: I- } \\
\text { The exploration and mining of deposits } \\
\text { of oil and natural gas and other hydro- } \\
\text { carbon fluids; . . } \S 1 \text { The Union may } \\
\text { contract with State-owned enterprises } \\
\text { or private, carrying out activities refe- } \\
\text { rred to in sections I to IV of this article } \\
\text { and complying with the conditions es- } \\
\text { tablished by law. } \S 2 \text { The law referred } \\
\text { to in } \S 1 \text { shall be provided on: I- the se- } \\
\text { curity of supply of petroleum products } \\
\text { throughout the national territory; II- the } \\
\text { recruitment conditions;III- the structure } \\
\text { and tasks of the Union's monopoly re- } \\
\text { gulator; }\end{array}$ \\
\hline
\end{tabular}

The stated purpose of the Constitutional Amendment was to delegate to Congress the authority to enact laws governing the oil and gas industry (Congresso Brasileiro [Brazilian Congress], 1995).

\section{THE PETROLEUM LAW (LAW 9,478/1997) AND THE ANP}

Two years after the Constitutional Amendment, the Government published the Law 9,478/1997 (BRAZIL, 1997), known as the Petroleum Law. This law created the ANP -Agência Nacional de Petróleo, Gás Natural e Biocombustíveis [National Regulatory Agency of Petroleum,

ou transferidas, total ou parcialmente, sem prévia anuência do poder concedente. $\S 4^{\circ}$ - Não dependerá de autorização ou concessão o aproveitamento do potencial de energia renovável de capacidade reduzida. 
Natural Gas and Biofuel] — and established the concession system for the research and production of Brazilian oil, gas and other fluid hydrocarbons.

As with every regulatory agency in Brazil, the ANP is an independent agency and was inspired by the United States model (BINENBOJM, 2005).

In the U.S., "[s]ome federal agencies within the Executive Branch are called 'independent agencies' because - unlike others - their leaders cannot be fired by the President once they have been confirmed for a term of specific years."(MCALLIN, et. al, 2005). Pursuant to the Law 9,478/1997, the ANP may have five Directors on its Board of Directors, each designated by the President, and approved by the Federal Senate. Each Director is then confirmed for a mandate of four years.

The objective of the ANP are, among others, to promote the regulation of the petroleum industry and to contract, and supervise the economic activities of the petroleum industry, pursuant to Article 8 of the Law.

"To achieve its purposes, the Concessions Law establishes that ANP shall administrate the rights related to the exploration and production activities, including contracting with private or state-owned companies, pursuant to Article 21 of the Law. ANP shall also award Concession Contracts for the exploration, development and production of oil and gas, issue authorizations related to these activities, supervise the enforcement of the contracts, as well as implement the public policy defined for the energy sector." (ZACOUR, at. al. 2012)

2 Original Version: “Art. 177. Constituem monopólio da União: I - a pesquisa e a lavra das jazidas de petróleo e gás natural e outros hidrocarbonetos fluidos; $\S 1^{\circ} \mathrm{O}$ monopólio previsto neste artigo inclui os riscos e resultados decorrentes das atividades nele mencionadas, sendo vedado à União ceder ou conceder qualquer tipo de participação, em espécie ou em valor, na exploração de jazidas de petróleo ou gás natural, ressalvado o disposto no art. $20, \S 1^{\circ}$. "After Amendment 9 of 1995: “Art. 177. Constituem monopólio da União: I - a pesquisa e a lavra das jazidas de petróleo e gás natural e outros hidrocarbonetos fluidos; $\S 1^{\circ} \mathrm{A}$ União poderá contratar com empresas estatais ou privadas a realização das atividades previstas nos incisos I a IV deste artigo observadas as condições estabelecidas em lei. $\S 2^{\circ} \mathrm{A}$ lei a que se refere o $\S 1^{\circ}$ disporá sobre: (Incluído pela Emenda Constitucional n ${ }^{\circ}$ 9, de 1995) (Vide Emenda Constitucional no 9 , de 1995) I - a garantia do fornecimento dos derivados de petróleo em todo o território nacional; (Incluído pela Emenda Constitucional n ${ }^{\circ}$ 9, de 1995) II - as condições de contratação; III - a estrutura e atribuições do órgão regulador do monopólio da União;" 
In 2010, a new petroleum regulatory framework arose in Brazil. Three new laws were published: (i) Law 12,276/2010; (ii) Law $12,304 / 2010$ and (iii) Law 12,351/2010. Those laws, along with Law 9.478/1997, were called a mixed regulatory regime by the ANP (ANP, 2012, c).

These new laws and the mixed regulatory regime will be explained below. The Concession Model and some aspects of its Bidding Rounds will then be explained in detail. Some information about current production, Operators, and the oil and gas market in Brazil will also be discussed.

\section{PRODUCTION SHARING CONTRACTS AND THE NEW UNITIZATION LEGAL FRAMEWORK}

The Pre-salt region - a large-scale oil and gas discovery in Campos Basin — put Brazil among the top ten oil producers in the world:

Estimates of Brazilian pre-salt reserves indicate a potential for 70 to 100 billion barrels of oil equivalent - boe (sum of oil and natural gas), but the exploration process for this wealth of resources is still in its early stages. (BRAZIL, 2013, a)

According to a study prepared by Ernst \& Young in partnership with FGV Projetos, the deposits discovered in the pre-salt sedimentary basins of Campos and Santos offshore São Paulo and Rio de Janeiro (in the Southeast region), should provide the country with an income of US\$28 billion from oil exports in 2020. According to the study, export volumes of 600 thousand barrels per day are expected by the end of this decade. If these figures are confirmed, this will be an increase of $73 \%$ in relation to 2010, equivalent to US\$ 16.1 billion. (BRAZIL, 2013, b)

When the discovery of the Pre-salt area was announced, it ignited many debates in the Congress and among Brazilian society (SERRA, 2013). As is widely known, the main point of contention was whether the Sovereign Government should leave the nation's wealth in the hands of International Oil Companies or its state company, Petrobras. On the other hand, some wondered whether it would be economically and structurally feasible for Petrobras to explore and develop all fields in the area. Issues related to international policy and constitutional 
matters also arose.

After more than a year of debates, and many proposed laws, Law 12,351/2010 -the Production Sharing Agreement Law (PSA Law) was enacted (BRAZIL, 2010, a). This law introduced a new regime to the Brazilian oil and gas industry, the main features of which are described by ZACOUR at. al. (2012).

Usually, under the production sharing system, the host State (owner of deposits), typically through its state-owned company 100\% public (National Oil Company-NOC), enters into a contract with an oil company investor (International Oil CompanyIOC), also called by the industry as "Contractor." These activities are performed at IOC's account and own risk. Once held a commercial discovery, the IOC is entitled to recover its investments through a portion of the production, known as "cost oil." After deducting the costs of production according to specific methodology established in the Contract, the "profit oil" is shared between the host State and the IOC. The model introduced by the PSA Law also follows this basic structure. (ZACOUR, 2012)

The Pre-salt area is known as "a grande picanha azul," which translates to "the big blue steak," a reference to the area's similarity to a Brazilian prime cut of steak and its reputation as the premier oil and gas region in Brazil; its shape is similar to the Pre-salt polygon.

The production of oil and gas in the geographical area defined under the law will be controlled through Production Sharing Agreements. The map below shows in pink the "Pre-salt" area (BRAZIL, 2012, d), subject to this regime.

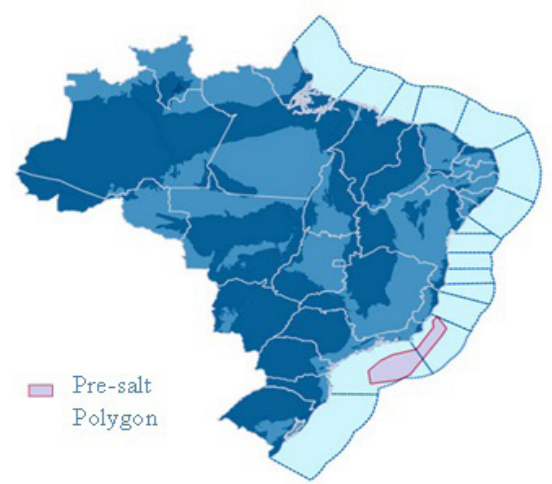

Figure 1: Brazilian offshore zone detaching Pre-salt Polygon.Source: ANP, 2012, c.Mapa Brasil Almada.jpg 
Production Sharing Agreements, in Brazil, however, are going to be unique in one aspect: Besides the regulatory agency, ANP, and Petrobras, another state company will sign this contract: Pré-sal Petróleo S.A. -PPSA [Pre-Salt Petroleum Co.] (BRAZIL, 2010, d).

for:

The PPSA, accordingly SILVA(2012), will be mainly responsible

a) conducting the management, audit, and inspecting and supervising of petroleum activities performed under PSCs;

b) authorizing the bidding processes related to the exploration and production of pre-salt areas;

c) representing the Government, through the operational committees, in

consortiums incorporated for the execution of PSCs; and

d) representing the Government in case of unitization in the presalt and strategic areas

PPSA is a new player in oil and gas industry in Brazil, and to it was given a great deal of power by Law 12,304/2010 (BRAZIL, 2010, d). Despite its privileged position in the operational committee, PPSA bears no risks in the exploration and production of hydrocarbon, pursuant the article $8^{\circ}, \S 2^{\circ}$ of Law 12,351/2010. All the risks and costs will be borne by Petrobras and the IOCs, if they are partners in the venture.

Pursuant to the PSA Law, the Pre-salt area must be developed under a Production Sharing Agreement - PSA. In addition, any other area recognized as a "strategic area" by an Executive Decree must also be developed under the PSA model (BRAZIL, 2010, a).

This rule was strongly criticized, for many reasons. First, Brazil is known as a politically stable country for international oil and gas investments because of its legal and political consistency (ERNEST \& YOUNG, 2011). The law ignited a storm of controversial issues and created an atmosphere of uncertainty for international investors.

Some commentators have argued that the President now has too much power. They argue that although the law provides some parameters, in theory, any area in Brazil can now be declared a "strategic area" for oil and gas exploration purposes, once it has been recognized as strategic area simply as a result of a Presidential Decree.

Why is this so relevant for international investors? Because under the PSA regime, Petrobras will be the only operator of all fields, holding a minimum of $30 \%$ of participating interests (BRAZIL, 2010, a).

Importantly, the remaining $70 \%$ of participating interests may be offered in a public bidding procedure, or they may not. In the first instance, the Union, through the Ministry of Mines and Energy, will 
enter into production sharing contracts directly with Petrobras. In the second instance, a public bidding procedure - through which Petrobras can improve its participating interests-will determine who will be the partner (ZACOUR, et. al, 2012).

As a matter of fact, the Federal Union had never entered into any Production Sharing Agreements as of February 2013. In December 2012, a new law was enacted by the Congress that established royalty rates at $15 \%$. The Brazilian PSAs have not only "profit oil," as usually set forth in this kind of contract, but also will have two additional Government Takes: bonus and royalty (BRAZIL, 2012).

Once there is a determination of the royalties to be paid under the PSA model, the Agreement can be signed. It is expected that the first bidding round will occur in the second half of 2013, after the Eleventh Concession Round, although no official announcement has been made (FOLHA DE SÃO PAULO, 2013).

Local content regulation is under review by ANP. Because of the Regulatory Mixed Regime, ANP included the Onerous Assignment area within the LC regulation. Petrobras, during notes and comments period, argued the Production Sharing Regime (PSR) should also be included in the same rule, and the concept of goods should be reviewed to include expenditures not related to exploration and development to satisfy other required investments under the PSR.

Given Petrobras' request, the final proposal will likely be amended to include the PSR under the same regulation, absent some contrary action by the Government. Keeping the same rules for the PSR demonstrates that the $\mathrm{LC}$ rules are of great importance to the Brazilian Government because the rules may increase Petrobras' costs, thus reducing the government's profit-oil lift .

To date, ANP has not announced any Public Hearing about the contract model to be adopted by Brazil for development of oil and gas reservoirs under the Production Sharing Agreement regime (ANP, 2013, c).

Meanwhile, some issues remain unsolved. First, the law did not address the issue if a company makes an uneconomical offer, which Petrobras do not want to be obliged with. There is no clear answer, but, in other public actions, the Government may refuse to sign a contract the it believe is unfeasible and the law that deals with public actions in Brazil is usually applied alternatively.

3 The term "Government Take" was also used in the Law 9,478/1997 and in the Law 12,351/10. In Brazil, the term has a different meaning than it generally has in the rest of the world. In this country, "Government Take" only refers to: assignment bonus, royalty, special participation and payment for the retention and occupation of the area (Law 9,478/1997, Article, 45 and Law 12,351/10, article 42), unlike other countries which consider also taxes and fees. (BRAZIL, 1997 e 2010, a) 
Moreover, is it going to be feasible for Petrobras to performance as an operator in all PSA? It will probably depends on if the company growth will be in the same pace as the improvement of exploration and production, which will be designated by the Brazilian Government. Finally, theses questions are not constitutional ones, so further legislation may address this issues and any other adaption it may be need, respecting all vested rights, which are constitutionally protected.

\subsection{The new Unitization framework}

Professor SMITH, et al., (2010) defines Unitization as "the cooperative exploitation of a reservoir by all interest owners so that the reservoir is developed as if it were owned and controlled by a single entity."

Law 12,351/2010 not only introduced the Production Sharing Agreement to the Brazilian Legal System, but also enacted a new legal framework for Unitization in Brazil. This Act also revoked article 27 of Law 9,478/1997, which was the sole law regulating Unitization at that moment (BRAZIL, 2010, a).

Under the Law 9,478/1997, article 27, there had been celebrated four Unitization Agreements (in Portuguese: "Acordos de Individualização da Produção") .The first one was approved in 2007 and involved Albacora e Albacora Leste fields. In the next year, ANP approved the Agreement to Mangangá e Nautilus fields. Then, in 2009, two more Agreements were approved, the first for the fields of Camarupim and Camarupim Norte; and a second for the Campos de Lorena and Pardal fields (BRAGA and SZKLO, 2012).

It is important to emphasize that the new Act revoked the previous provision determining that only different interest owners may be subject an Unitization. The reference to different interest owners - expressed in Law 9,478/1997- was withdrawn by the new Act. Thus, in the Brazilian legal system, it is possible that a single company may submit and receive approval for a Unitization Agreement, even if the single company is the interest owner and the operator of the two areas (BRAGA and SZKLO, 2012).

This possibility was contemplated by the new law considering that the reservoir may underline areas under different legal regimes -consequently, under different royalties rates, taxes regimes and obligations. Analyzing the contracts, it is possible to say that even under the revoked law this issue might have arisen, given, for example, the different contractual obligations for Local Content.

Since 2010, all Unitization Agreements, under all oil and gas contracts celebrated in Brazil -including Concession Contracts, have been regulated according to Law 12,351/2010, as follows (BRAZIL, 
2012, a):

Art. 33. The unitization of production activities of oil, natural gas and other hydrocarbons shall be set up whenever the field should extend beyond the block granted or contracted under the production sharing model.

$\S 1$ The concessionaire or contractor under the production sharing model shall inform the ANP that the field shall be subject to an unitization of production agreement.

$\S 2$ The ANP shall set forth the deadline for the parties to celebrate the unitization of production agreement, in observance of the guidelines issued by the CNPE.

Art. 34. The ANP shall regulate the procedures and guidelines used to prepare the unitization of production agreement, which shall define:

I - the participation of each of the parties in the unitized field, as well as the hypotheses and criteria for its revision;

II - the development plan pertaining to the area subject to unitization of production; and

III - conflict resolving devices

Art. 35. The unitization of production agreement shall appoint the respective field operator.

Art. 36. The Federal Government, represented by the public company referred to in $\$ 1$ of art. 8 , and based on surveys carried out by the ANP, shall celebrate an unitization of production agreement with the parties in cases where fields belonging to the pre-salt area and other strategic areas should extend beyond areas not being shared or assigned. The future concessionaire or contractor under the production sharing model shall be obliged by the terms and provisions of such unitization of 
production agreement.

$\S 1$ The ANP shall provide the public company referred to in $\S 1$ of art. 8 with all information required to celebrate the unitization of production agreement.

$\S 2$ The exploration and production model to be adopted in the areas dealt with in the head is independent of the model being used in adjoining areas.

Art. 37. The Federal Government, represented by the ANP, shall celebrate an unitization of production agreement with the interested parties after the respective evaluations of fields not located within the pre-salt areas or other strategic areas and extending beyond non-assigned areas. The future concessionaire shall be obliged by the terms and conditions of such agreement.

Art. 38. The ANP may enter into contract directly with Petrobras in order to carry out the field evaluation activities provided in arts. 36 and 37.

Art. 39. The unitization of production agreements shall be submitted to previous approval by the ANP.

Art. 40. Once the term set forth in $\$ 2$ of art. 33 will have elapsed, and no agreement is reached between the parties, the ANP shall determine, in up to 120 (one hundred and twenty) days, and based on a technical opinion, the form by which rights and obligations over the field shall be appropriated and shall notify the parties to sign the respective unitization of production agreement.

$\S$ sole paragraph:: The refusal to sign the Unitization Agreement will imply the termination of concession or production sharing agreement. ${ }^{4}$

4 Art. 33. O procedimento de individualização da produção de petróleo, de gás natural e de outros hidrocarbonetos fluidos deverá ser instaurado quando se identificar que a jazida se estende além do bloco concedido ou contratado sob o regime de partilha de produção. $§ 1$ o $\mathrm{O}$ concessionário ou o contratado sob o regime de partilha de produção deverá informar à ANP 
Analyzing Article 40, BRAGA and SZKLO (2012) concluded that the effects when the involved parties decline to sign the agreement are not sufficiently clear. They note that the law did not distinguish between a situation when both parties refuse to sign and a situation in which only one party refuses to sign; in this last situation, the signing party might continue to develop and produce. They also call attention to the fact that the Unification Agreement may involve only part of an area in the block under concession or PSA, and yet the termination would apply to the entire contract.

This scenario might occur if the ANP interprets the law literally. However, the article may also be constructed as authorizing the partial termination of a contract. Although this interpretation might be controversial, it seems more aligned to the public interest, given that the development and production of oil and gas is economically, socially, and politically important to the country.

On the other hand, an operator placed in jeopardy of the

que a jazida será objeto de acordo de individualização da produção. § 2o A ANP determinará o prazo para que os interessados celebrem o acordo de individualização da produção, observadas as diretrizes do CNPE. Art. 34. AANP regulará os procedimentos e as diretrizes para elaboração do acordo de individualização da produção, o qual estipulará: I - a participação de cada uma das partes na jazida individualizada, bem como as hipóteses e os critérios de sua revisão; II - o plano de desenvolvimento da área objeto de individualização da produção; e III - os mecanismos de solução de controvérsias. Parágrafo único. A ANP acompanhará a negociação entre os interessados sobre os termos do acordo de individualização da produção. Art. 35. O acordo de individualização da produção indicará o operador da respectiva jazida. Art. 36. A União, representada pela empresa pública referida no § 1o do art. 80 e com base nas avaliações realizadas pela ANP, celebrará com os interessados, nos casos em que as jazidas da área do présal e das áreas estratégicas se estendam por áreas não concedidas ou não partilhadas, acordo de individualização da produção, cujos termos e condições obrigarão o futuro concessionário ou contratado sob regime de partilha de produção. § 1o A ANP deverá fornecer à empresa pública referida no $\S 1$ o do art. 8 o todas as informações necessárias para o acordo de individualização da produção. $\S 20 \quad \mathrm{O}$ regime de exploração e produção a ser adotado nas áreas de que trata o caput independe do regime vigente nas áreas adjacentes. Art. 37. A União, representada pela ANP, celebrará com os interessados, após as devidas avaliações, nos casos em que a jazida não se localize na área do pré-sal ou em áreas estratégicas e se estenda por áreas não concedidas, acordo de individualização da produção, cujos termos e condições obrigarão o futuro concessionário. Art. 38. A ANP poderá contratar diretamente a Petrobras para realizar as atividades de avaliação das jazidas previstas nos arts. 36 e 37. Art. 39. Os acordos de individualização da produção serão submetidos à prévia aprovação da ANP. Parágrafo único. A ANP deverá se manifestar em até 60 (sessenta) dias, contados do recebimento da proposta de acordo. Art. 40. Transcorrido o prazo de que trata o $\S 20$ do art. 33 e não havendo acordo entre as partes, caberá à ANP determinar, em até 120 (cento e vinte) dias e com base em laudo técnico, a forma como serão apropriados os direitos e as obrigações sobre a jazida e notificar as partes para que firmem o respectivo acordo de individualização da produção. Parágrafo único. A recusa de uma das partes em firmar o acordo de individualização da produção implicará resolução dos contratos de concessão ou de partilha de produção. 
Oil \& Gas Industry in Brazil - Laís Palazzo Almada and Virgínia Parente

termination of a contract might attempt to avoid the termination by farming out that area ${ }^{5}$ to the other common reservoir operator or relinquishing the area corresponding to the reservoir that overlaps the block, if the operator cannot reach an agreement.

\section{THE ONEROUS ASSIGNMENT CONTRACT (LAW 12,276/10)}

In conjunction with the enactment of the Production Sharing Agreement Law, Brazil enacted the Law 12,276/2010. The objective of this law was to allow Petrobras to attract new investors and to keep the Federal Union as the main shareholder, holding at least $50 \%$ of the voting shares (SOUZA, 2011). In 2012, the Federal Union had 50,3\% of the voting shares and $28,7 \%$ of the total shares. (PETROBRAS, 2012).

The law authorized the Federal Union to sign the Onerous Assignment with Petrobras, giving the company the right to explore and to produce up to five billion barrels equivalent of crude oil. Also, under this law, the payment was made by Petrobras in federal debt securities.

At the same time, the law provides that the Federal Union might subscribe and pay Petrobras' shares with federal debt securities. Souza notes that according to Brazilian Corporation Law, the Government could not instead pay shares with oil and gas in place, because the value of the asset could not be reviewed in that situation (SOUZA, 2011). At the end of the day, the Brazilian Government increased its participation in Petrobras stocks through its national oil and gas proved reserves contracted with Petrobras in the Onerous Assignment.

The table below shows the areas, or reservoirs, subject to the Onerous Assignment (Área do Contrato), the volume of each area (Volume da Cessão Onerosa) and also the oil price per barrel considered (valor do barril) in the contract. Peroba area was nominated as a backup area, in case the production in other areas did not achieve the volume foreseen.

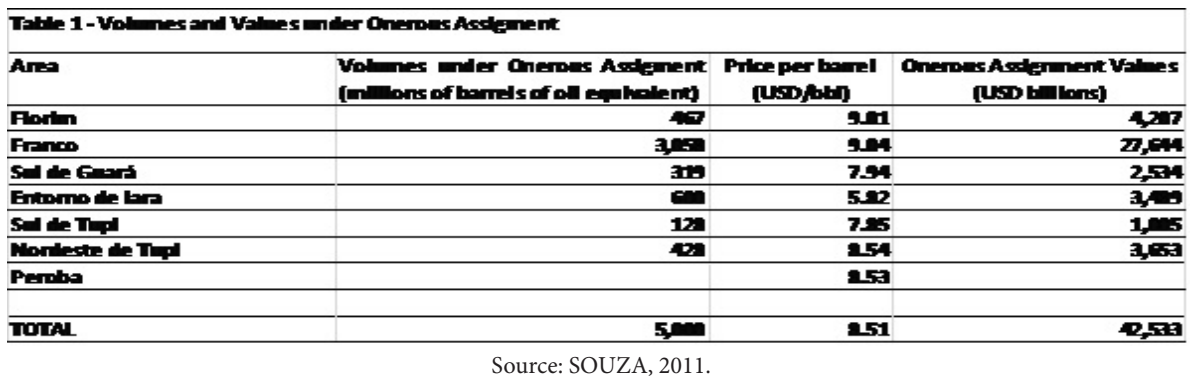

5 Only in the Sixth Round, the Concession Contract expressly establish rules to assign only some areas of the block under concession (ANP, 2004). On the other hand, Fifth Round Contract, for example, establishes the power of assignment, totally or partially, although partially is not contractually defined (ANP, 2003). 
ANP contracted with Gaffney, Cline and Associates (GCA) for an audit and "valuation" of the resource (ANP, 2011,d). The report --Review and evaluation of ten Selected discoveries and prospects In the pre-salt play of the deepwater Santos basin, Brazil-supported the contract signed by the Brazilian Government and Petrobras to development of the above-mentioned areas (BRAZIL, 2011, d).

ZACOUR, et. al, (2012) explain, in short, the main characteristics of the onerous assignment contract:

[T] he parties of this Contract, signed in September 2010, are: the Union, represented by the Minister of Mines and Energy, the Minister of Finance and the General Attorney of the National Treasury, and Petrobras. The ANP has integrated the Contract as a regulator and controller.

The purpose of the Contract is the execution of activities of exploration and production of oil and natural gas in certain areas, as specified in the annex to the Contract. Operational risk is all of the Assignee (Petrobras).

With respect to geological risk, it is possible to say that there is no exploratory risk to the Assignee (Petrobras), considering that the Contract establishes mechanisms to ensure that Petrobras will have the right to produce the total amount of 5 billion barrels of boe.

The term of the Contract is 40 (forty) years as from the date of its execution (clause 5.2). This period may be extended by the Assignor by a maximum of 5 (five) years, upon request of Assignee (Petrobras) (clause 5.3)....

Petrobras cannot transfer any of its rights under the Onerous Assignment Contract (art. 1, §6, of Law 12,276/2010). The consideration to be paid by Petrobras is composed of: (a) the price paid by the Assignee (Petrobras) to explore and produce oil and natural gas to the limit of 5 (five) billions of barrels of oil equivalent of oil, in areas of pre-salt (art. $1^{\circ}, \S$ 3, Law 12,276/2010); and (b) the royalties (art. 5 of the Law), which will be paid, monthly, in an amount 
corresponding to $10 \%$ (ten percent) of production of oil or natural gas...

The property of oil extracted, up to the limit of 5 (five) billion of barrels of oil equivalent of petroleum, as well as the costs of operations, will be - in its entirety - of the Assignee (Petrobras) (art. $1^{\circ}, \S 1$, and art. $4^{\circ}$ of Law 12,276/2010).

Finally, the control of the operations to be performed by Petrobras will be up to the National Agency of Petroleum, Natural Gas and Biofuels - ANP (art. 7 of Law 12,276/2010).

As prescribed in Article 5, Special Participation (explained below) is not required for the production of this amount of oil. The State of Rio de Janeiro - the main beneficiary of this Government Take - argued the unconstitutionality (STF, 2012, a) of this article in the Supreme Court in November 2011. As of February 2013, no in limine or final decision had been reached.

\section{The Concession Regime and the exploration and production in Brazil}

When the Petroleum Law was enacted, Petrobras had already been operating and producing in Brazil. As a transition, the law allowed Petrobras to carry on the operations in areas where it had already been working. The law also determined that Petrobras should sign Concession Contracts in each of these areas. These contracts came to be known as "Round Zero" (ANP, 2011, b, f). As determined in Article 33 of Law 9,478/1997, 397 contracts were signed with Petrobras in 1998.

Since then, ANP has promoted ten annual Bidding Round of Blocks for Exploration and Production of Oil \& Natural Gas. This is a mandatory procedure, accordingly the Law 9,478/1997, Article 23:

Art. 23. Oil and gas exploration, development and production activities shall be exercised by means of concession agreements preceded by public bids, as set forth herein, or by the production sharing model in the pre-salt and strategic areas, as per the specific laws thereto.

Prior to August 2012, there were seventy seven different economic groups performing exploration and production activities in 
Brazil, including International Oil Companies and Brazilian independent producers. Among them, thirty eight are foreign (ANP, 2012, f).

A summary of each Round can be found on the ANP website (ANP, 2013, h). BRAGA and CAMPOS give a good overall view of the Bid's procedure:

ANP launched the bid notice and the draft of the concession agreement and discusses its terms in a public hearing. As soon as the bid notice is launched, begins the process of bidder's qualification by the CEL [Comissão Especial de Licitação [Bidding Special Committee]]. The documentation required in Brazilian bidder's qualification process is divided into three categories: i) technical, ii) economic and financial; iii) legal and fiscal. In Brazil, companies are classified in non-operator and operator. The operator classification is still divided, according to the area of operation, in: A (onshore, shallow and deep water), $B$ (onshore and shallow water) and $C$ (onshore). The ANP allows individual companies without experience to participate of the Bidding Round, since they were qualified as operators $B$ or $C$, through detailed assessment of the technical staff member's resumes, confirming relevant experience in petroleum exploration and exploitation. The Brazilian qualification process is linked to Bidding Rounds. (BRAGA and FERREIRA, 2008).

After being qualified by the CEL, companies must pay a participation fee and submit financial guarantees in order to be allowed to present offers on the public section, previously scheduled by ANP (BRAZIL ROUNDS, 2008).

The offer should consist of three components: i) signing bonus, which has [a]weight [of] 4 in the bid evaluation, ii) Minimum Exploration Program - PEM, also with [a] weight [of] 4, and iii) local content, weighing 2, divided into 0.5 for the exploratory phase and 1.5 to development and production phase. Each block offered in the bid has a minimum signature bonus, and companies can only offer amounts equal to or greater than this. The PEM is expressed in work units (UT) and must be 
[greater than] [] zero, following the parameters of equivalence with exploratory activities. Regarding local content, there is a spreadsheet with the minimum percentages required for each item of the subsystems (geology and geophysics, drilling, completion and evaluation, operational support, system production and collection of plant).

ANP has its own system of bid evaluation, developed specifically for the offers processing in order to provide transparency and speed in the process. The bid evaluation's result is show [n] to the participants of public section almost immediately after the announcement of the final offer. In the event of a tie, tied companies must submit a new offer. All the criteria must be offered with equal or greater values than the first offer. Petrobras has the preference, if one of tied companies (BRAGA and FERREIRA, 2008).

On completion of public section and disclosure of the Bidding Round results, companies must submit the required documents for the signing of the concession agreement, in accordance the provisions of Bid Notice. (page 13)

It is important to note that the Eighth Round was suspended, under judicial order (ANP, 2013, f). The Ninth Round had forty one blocks, which were withdrawn as determined by Resolution 06/2007 CNPE - Conselho Nacional de Política Energética [National Council for Energy Policy], after Petrobras announced its discovery of potential large-scale reserves in the Brazilian pre-salt layer. For many years, the situation continued unresolved, but in 2012, ANP Board Resolution $\mathrm{n}^{\circ}$ 593/2012 (ANP, 2013, a) was enacted and the following notice was posted on its website:

The ANP began the process of refunding the Participation Fees and Bid Bond relating to areas of the Eighth Round.

The companies that have paid the Participation Fee for the sectors that have been removed from the Eighth Round, by means of a Resolution of Board of Directors, will have their Participation Fees 
refunded, as well as the Bid Bond not associated with a valid proposal. (ANP, 2012, b)

Unfortunately, the last Round had taken place in 2008, shortly before the debates about the Pre-salt area began. At that time, the Tenth Round only "[o]ffer[ed] 130 blocks, all located in onshore basins, this Bidding Round has attained its goal of attracting small and mediumsized companies, alongside with major oil companies." (ANP, 2013, e)

After a hiatus of almost four years, the Federal Government announced the next Bidding Round of Blocks for Exploration and Production of Oil \& Natural Gas:

\begin{abstract}
President Dilma Rousseff authorized today (9/18/2012) the 11th Brazil Round for concession of exploratory blocks for petroleum, that will take place on May 2013, on a date to be set by ANP. The blocks to be offered will be disclosed by the Agency in the next few days.
\end{abstract}

The promotion of the 11th bidding round is conditioned to the approval of the royalties' law by the Brazilian Congress. (ANP, 2012, e)

In December, 18, 2012, The National Council for Energy Policy authorized ANP, on 01/11/2013, to hold the Eleventh Bidding Round (ANP, 2013, g), which will offer blocks in seventeen sectors, totaling 121.2 thousand $\mathrm{km}^{2}$ in basins of new borders and mature basins. The area being offered covers nine sedimentary basins and forms 172 blocks, on shore and offshore (ANP, 2013, b).

The exploratory blocks on shore are: Espírito Santo Basin, Parnaíba Basin, Potiguar Basin, Recôncavo Basin, Sergipe-Alagoas Basin. The Offshore Sectors, located on shallow waters, are: Barreirinhas Basin, Foz do Amazonas Basin. These areas can be seen on Appendix I (ANP, 2013, d).

The Eleventh Bidding Round will be governed by Resolution $n^{\circ} 27 / 2012$, which approves the Regulations dealing with procedures for bidding on the acquisition of blocks intended for the hiring of exploration and production activities of oil and natural gas under the concession regime. An unofficial version in English can be found at ANP website (ANP, 2013, a). Also, information about areas offered in the Eleventh Round, qualification to participate, and data package area available in English (ANP, 2013, c). 


\subsection{Production and Government Takes under Concession Regime}

According to Petroleum Law, the companies that operate in Brazil must be established under Brazilian law. "Foreign companies are allowed to participate in Brazil Round []. In the event of success, the winner company must provide performance guarantees to a Brazilian affiliate who will sign the Concession Agreement." (ANP, 2007).

Many international companies have both a Brazilian affiliate and a successful business in Brazil, although Petrobras is still responsible for more than 90\% of all oil and gas produced in Brazil (ANP, 2012, a).

Besides Petrobras, the main producers in Brazil and their countries of origin are: (1) Statoil Brasil (Norway); (2) Shell Brasil (Anglo-Dutch); (3) BG Brasil(United Kingdom); (4) Sinochem Petróleo (China); (5) Manati (Brazil); (6) Petrogal Brasil (Portugal); (7) OGX (Brazil); (8) BP Energy (United Kingdom); (9) Repsol (Spain); (10) ONGC Campos (India) (ANP, 2012, a). It is important to remember that, according to Brazilian law, all these companies are Brazilian (BRAZIL 1997), although they are affiliated of foreign companies.

The table below shows the most productive fields in Brazil, including the Statoil and Shell fields (ANP, 2012, a). Actually, Chevron, operating the Frade field, was usually figured as one of these major producers before its first oil spill, which occurred on November, 2011 (Chevron, 2012). In January, 2011, Frade was the Ninth Field in total production (ANP, 2011, c).

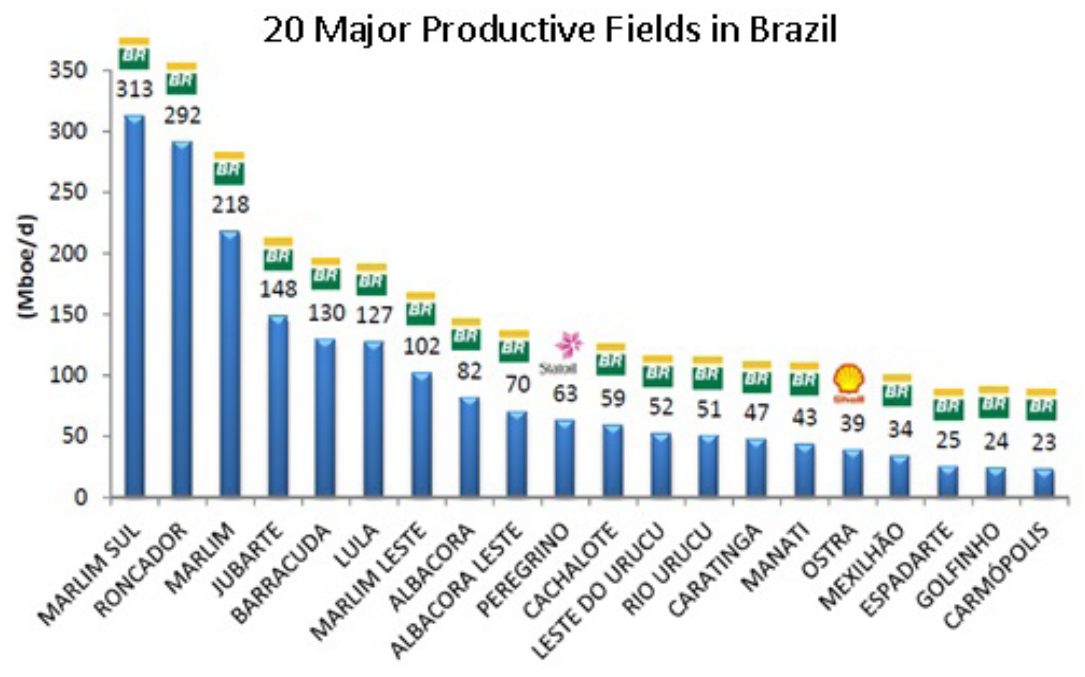

Source: ANP, 2011, c. 
Among these fields, only Leste Urucu, Rio Urucu and Carmópolis are onshore. The Brazilian oil and gas industry is remarkable for its offshore production. Roughly, $90 \%$ of oil production is offshore and about $75 \%$ of gas production is offshore. This difference can be attributed to Urucu Field (Leste Urucu, Rio Urucu and Sudoeste do Urucu), a major non-associated gas productor, located in Solimões Basin, Amazonas (ANP, 2012, a).

The average of API Gravity from Brazilian oil-defined for The American Petroleum Institute-is about $24^{\circ}$. The production is represented for: $9 \%$ of light oil $\left(>=31^{\circ}\right.$ API), $57 \%$ of medium oil $\left(>=22^{\circ} \mathrm{API}\right.$ e $\left.<31^{\circ} \mathrm{API}\right)$ e $34 \%$ of heavy oil, $\left(<22^{\circ} \mathrm{API}\right)$, accordingly to the ANP's classification (ANP, 2012, a).

Under the Concession System, the Operator acquires the ownership of the hydrocarbons once produced. At the same time, there emerges a duty to pay royalties.

Royalties, under the Concession regime, are ten percent, but can be reduced to as little as five percent. In deciding to reduce royalties, ANP will consider the geological risks, the production expectations, and other relevant factors. The majority of the fields pay royalties of ten percent (SERRA, 2013).

Royalties are due on the last workday of the month subsequent to the production. In the Concession system, royalties are not paid in kind. To determine the price of the oil, ANP considers physio-chemical composition, TBP (True Boiling Point) curve, API gravity and sulfur content. This data is compared to Brent Oil and other crude oil benchmarks (ANP, 2009).

The graph below shows the amount of royalties paid, per year, since ANP was established.

\section{Royalties Revenues - Brazil (US\$ millions)}

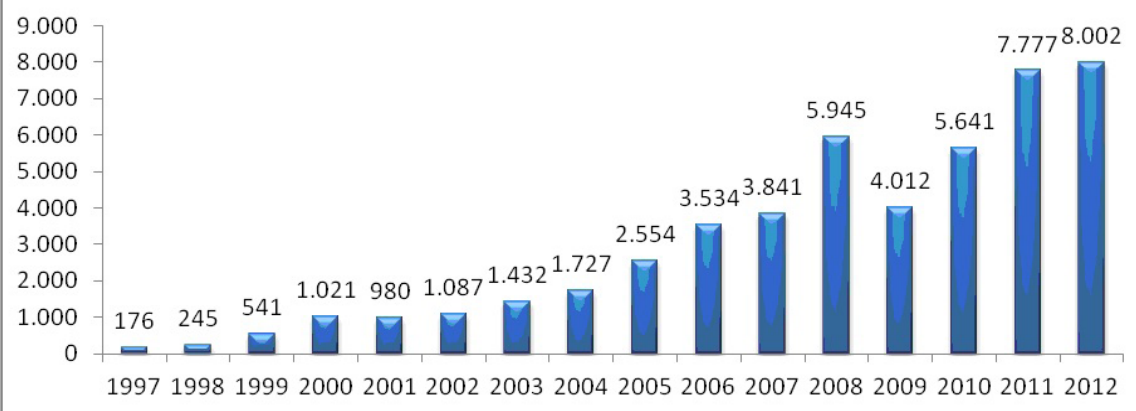

Source: Authors. 
Before ANP was established, royalties were five percent of the production. These royalties were calculated and paid directly by Petrobras for the beneficiaries, according to Law 2,004/1953 and Law 7.990/1989 (BRAZIL, 1953 e 1989).

Another important Government Take paid in Brazil is the "Participação Especial - PE" [Special Participation]. Although only fields with great production volumes pay Special Participation, this Government Take collects more money than does Royalty. Below, it is possible to verify the amount of Special Participation and compare it with Royalties payments above.

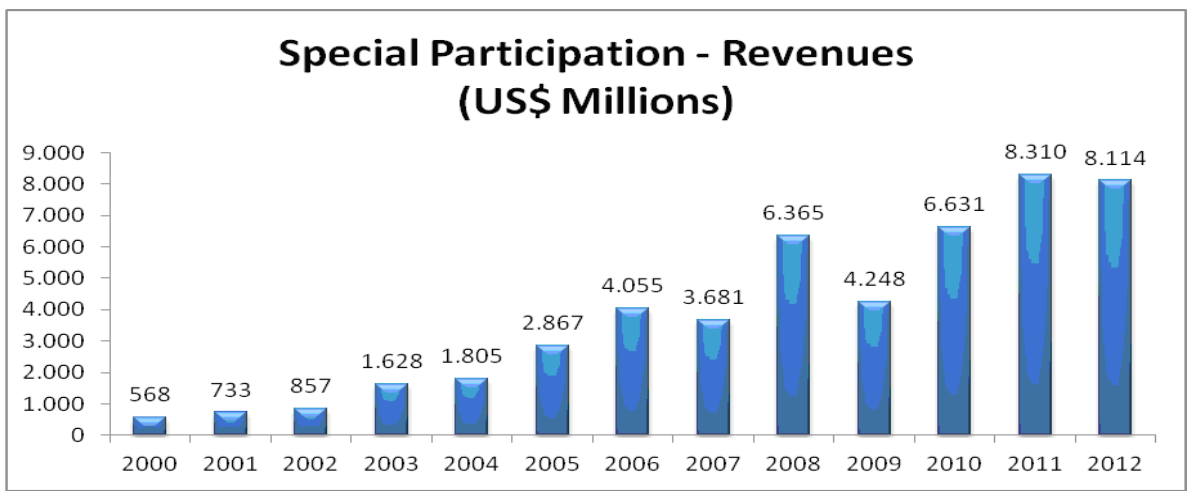

Source: Authors.

In 2009, sixteen fields paid Special Participation; this number increased to nineteen in 2012. Without exception, like every other field in Brazil, theses fields also pay royalties.

In contrast to royalties-that is, a fixed percentage of productionthe calculation of Special Participation is complex. The tax basis considers not only the profits, but also some of the costs, which can be deduced according to some of ANP's rules (Portaria ANP 10/99 and Portaria ANP 58/2001).

On the other hand, rates are fixed in the Decree 2,705/1998 and will vary, depending on: (1) production volume; (2) field location: onshore, offshore and offshore deeper than 400 meters (about 1,300 feet) under the sea; and (3) years of production, which stabilizes in the fourth year.

This decree provides twelve tables, with all the possible rates. The table below presents some examples of applicable rates to fields with more than four years of production. Each line in the graphic represents the three possible locations, and the rates increase as production increases. 


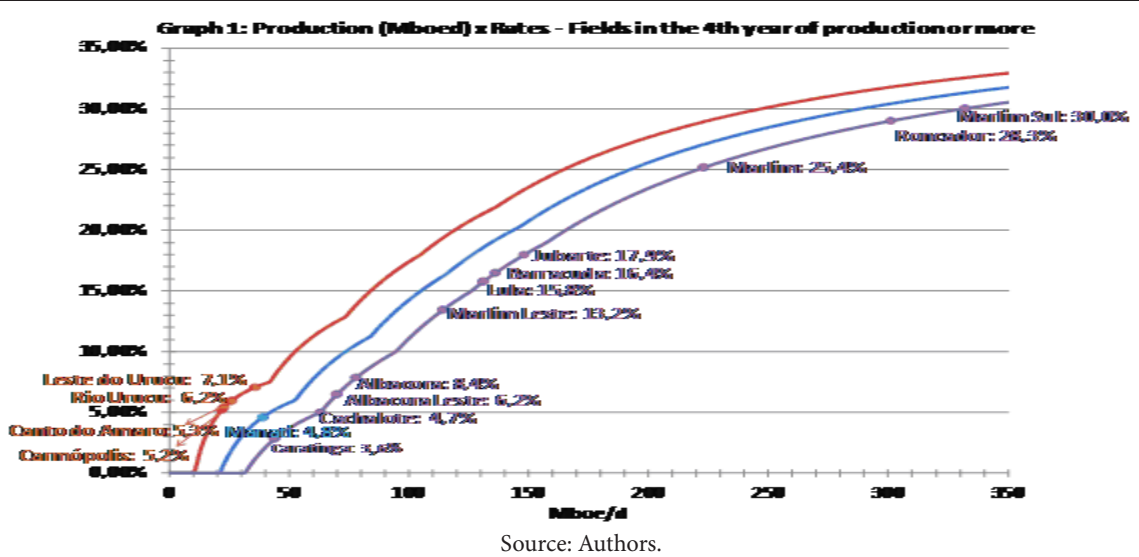

All the "Government Takes" are distributed according to the shares provided by Petroleum Law. The beneficiaries are the: (1) Federal Union; (2) Ministry of Science and Technology; (3) Navy; (4) Productive States; (5) Productive municipalities; and (6) States Fund 6 .

The Government Takes shares are a complex subject, and beyond the scope of this article. However, it is important to note that, beginning in December 2012, the revenues shares from the Concession Contracts are under legislative review. The Bill 2,565/2011 (PL ${ }^{\circ}$ 2,565/2011), approved as Law 12,734/2012, had its article 3 vetoed by the President, Ms. Rouseff. Article three aimed to establish a new share for the revenues of Concession Contracts already signed.

The effect of the veto is to maintain the rules of Petroleum Law. The Constitution, however, establishes a mechanism whereby a twothirds majority vote allows the Congress to override a Presidential veto of legislation, similar to the veto override provisions found in the U.S. Constitution (Constitution of The United States, Article I, Section 7, (2)). During its December, 12, 2012, session, the Congress approved an "urgent regime" for the veto voting. This would mean that this veto would be appreciated first, disregarding other more than 3,000 ones that are waiting to be analyzed by Congress.

Against this decision, two writs [Mandados de Segurança] were presented to the Supreme Court. The plaintiffs sustained that: (i) the "urgent regime" violates the due process of law, once it was not designed to veto; (ii) the due process of law was also violated because the Congress's procedures rules were not followed; and (iii) the "regime" violates the precedence order and the principle of reasonableness (STF, 2012, b).

In the first writ, Justice Luiz Fux decided, in limine, to suspend the legislative process, stating that chronological order must be observed

6 This is a small share that is shared with all States, independent of whether there is production in their territory, or not. 
in appreciating the veto (STF, 2013). As of February, 2013, there is no final decision. In the second one, no opinion was delivered.

\section{CONCLUSION}

The oil and gas industry in Brazil has changed a great deal since the Constitutional Amendment of 1995. Although Petrobras is still the major player in this market, the mere fact that competition, introduced by the Concession Regime, has brought some new features and improvements to oil and gas industry in Brazil, resulting in significant volumes of production.

At the same time, Brazil has gained the status of being considered a stable country for International Oil Companies. Fortunately, some misleading events involving the Eighth Round and the Ninth Round, which were suspended, have been overcame, putting an end in any inconsistency that may have arose.

Additionally, the Eleventh Round recovers the attention to Brazilian oil and gas industry and has been appointed as a way to recover new investments and create opportunities in the country. It is expected that the first Production Sharing Agreement auction will occur still in 2013, although there is no official announcement yet. Notwithstanding, IOCs have great expectations about the model of Production Sharing Agreement to be adopted by Brazil.

In the meantime, oil and gas revenue sharing remains to be decided. From the investors' point of view, there should not be any concern. The amounts to be paid, under Concession Regime and under PSA, are already defined and not under debate in Congress. However, this is of great concern to the Government.

The Brazilian Government will also have to gauge the international reaction to the new regime after it goes into effect. Pré-sal Petróleo S.A.-PPSA remains unfamiliar even to Brazilian investors. On the other hand, the state owned company, Petrobras, is a consolidated and respected company worldwide, even when facing the ups and downs due to the domestic economic policy, holding back fuel prices to compromise with inflation target. Moreover, Brazilian Government has always shown consistency in oil and gas agreements and had never breached any contract, fostering a safe environment for long run investments.

The lessons learned from this experience show that structuring a robust legal framework to foster the necessary investments is not only a challenge for the Brazilian economy, but also one that has to be tackled by many emergent economies with newly hydrocarbon discoveries. 


\section{REFERENCES}

AGÊNCIA NACIONAL DO PETRÓLEO, GÁS NATURAL E BIOCOMBUSTÍVEIS (Brasil). Contrato de concessão para exploração, desenvolvimento e produção de petróleo e gás natural, 2003. http://www. brasil-rounds.gov.br/arquivos/contratos/ContratoR5.pdf

Concession agreement for the exploration, development and production of oil and natural gas, 2004. http://www.anp.gov.br/brnd/ round6/contrato/Contrato_R6_en.pdf

. Brazil Round 9. Qualification Guidelines, 2007. Available at http://www.anp.gov.br/brasil-rounds/round9/english/guia_da_rodada_R9.asp

. Manual de atividades: Preço mínimo de Petróleo, 2009. . Available at http://www.anp.gov.br/?dw=34326

. ANP RESOLUTION No. 27, OF 02/06/2011, 2011, a. http://www. brasil-rounds.gov.br/arquivos/Resolucao/Resolucao27_em_Substituicao_Portaria_ANP174_ingles_2011.pdf $\mathrm{br} /$ ? id $=2649$

A Rodada Zero, 2011, b. Available at http://www.anp.gov.

Boletim mensal de produção de Janeiro de 2011 [Monthly Production of January, 2011], 2011, c. Available at http://www.anp. gov.br/?pg $=62026 \& \mathrm{~m}=\& \mathrm{t} 1=\& \mathrm{t} 2=\& \mathrm{t} 3=\& \mathrm{t} 4=\& \mathrm{ar}=\& \mathrm{ps}=\& \mathrm{cache}-$ bust $=1350964809574$

. Certificação dos reservatórios do pré-sal, 2011, d. Available at http://www.anp.gov.br/?pg=39200\&m=cess\%C3\%A3oonerosa\&t1 =\&$\mathrm{t} 2=$ cess $\% \mathrm{C} 3 \% \mathrm{~A} 3$ oonerosa $\& \mathrm{t} 3=\& \mathrm{t} 4=\& \mathrm{ar}$

Review and evaluation of ten selected discoveries and prospects in the pre-salt play of the deepwater Santos basin, Brazil, 2011, e. http:// www.anp.gov.br/?dw $=39137$

$\mathrm{br} /$ ? $\mathrm{dw}=19443$.

Rodada Zero, 2011, f. Available at http://www.anp.gov.

Boletim mensal de produção de Agosto de 2012 [Monthly Production of August,2012], 2012,a.http://www.anp.gov.br/?pg=62026\&m=\&$\mathrm{t} 1=\& \mathrm{t} 2=\& \mathrm{t} 3=\& \mathrm{t} 4=\& \operatorname{ar}=\& \mathrm{ps}=\&$ cachebust $=1350922629461$ asp

. News, 2012, b. http://www.brasil-rounds.gov.br/ingles/noticias.

. O Regime Regulatório Misto [Mixed Regulatory Regime] , 2012, c. Available at http://www.anp.gov.br/?pg=57842.

. O Regime Regulatório Misto. Coordenadas do Pré-sal [Mixed Regulatory Regime-Pre-salt Coordenates], 2012, d. Available at http:// www.anp.gov.br/?id=2656\#coordenadas-poligono-pre-sal.

. Presidenta aprova a $11^{\text {a }}$ Rodada, 2012, e. Available at http://www. anp.gov.br $/$ ?pg $=61965 \& \mathrm{~m}=\& \mathrm{t} 1=\& \mathrm{t} 2=\& \mathrm{t} 3=\& \mathrm{t} 4=\& \mathrm{ar}=\& \mathrm{ps}=\& \mathrm{cach}-$ bust $=1350926194680$. 
Oil \& Gas Industry in Brazil - Laís Palazzo Almada and Virgínia Parente

Relação de Concessionários, 2012, f. Available at http://www.brasil-rounds.gov.br/portugues/lista_de_concessionarios.asp

ANP Board Resolution no. 593/2012, 2013, a. http://www.brasil-rounds.gov.br/ingles/devolucao_taxa.asp

Áreas oferecidas, 2013, ̄ b. http://www.brasil-rounds.gov.br/ round11/ingles_r11/areas_oferecidas.asp

. Brazil 11th Round. Oil\&Gas Bidding Round, 2013, c. Available at http://www.brasil-rounds.gov.br/index_e.asp

Mapa dos Blocos, 2013, d. Available at http://www.brasil-rounds. gov.br/arquivos/areas_oferecidas_r11/Mapa/Mapao_Blocos_R11.pdf

. Resumo da Décima Rodada de Licitações. Summary of the Tenth

Round of Public Tender, 2013, e. Available at http://www.brasil-rounds. gov.br/resultado_rodadas/RESUMO_round10.asp

. Resumo da Oitava Rodada de Licitações. Summary of the Eighth Round of Public Tender, 2013, f. Available at http://www.brasil-rounds. gov.br/resultado_rodadas/RESUMO_round8.asp

. Resolução no 3/2003 [ANP Board Resolution no. 03/2003], 2013, g. Available at http://www.brasil-rounds.gov.br/arquivos/Resolucao/Resolucao_n3_01_2013.pdf

. Rodadas anteriores. Former Rounds, 2013, h. Available at http:// www.brasil-rounds.gov.br/resultado_rodadas/RESUMO_round0.asp. BCB-DEPEC, 2013: Annual Exchange Average. Available at http://www.economaster.com.br/economia/index.php?option=com wrapper\&view $=$ wrapper\&Itemid $=241$.

BRAGA, Luciana Palmeira, and CAMPOS, Thiago Neves. A Comparative Study Of Bid Models Adopted By Brazil, Peru, Colombia And Uruguay To Granting Petroleum Exploration And Production Rights, 5 Journal of World Energy Law \& Business 94, 99; 1-19 (2012).

BRAGA, Luciana. SZKLO, Alexandre. A convivência de três espécies de contrato de petróleo internacional na área do pré-sal e as implicações para o processo de individualização da produção. [The three international petroleum contracts coexistence in pre-salt area and the impacts over the unitization process ] Available at: http://www.ibp.org.br/main. asp?team $=\% 7 B d 3595 f 92-d a e 4-46 c 5-8561-639617$ c6efd9\%7D.

BRAZIL, 1953. Brazilian Legislation, available at http://www.planalto. gov.br/ccivil_03/leis/L2004.htm.

. Brazilian Legislation, 1989. Available at http://www.planalto.gov. br/ccivil_03/leis/L7990.htm

. Brazilian Constitution, 1988. Available at http://www.planalto.gov. br/ccivil_03/constituicao/constituicao.htm

Brazilian Legislation. Constitutional Amendment 9, 1995. Available at http://www.planalto.gov.br/ccivil_03/constituicao/Emendas/ Emc/emc09.htm.

. Brazilian legislation, 1997. Available at http://www.planalto.gov. 
br/ccivil_03/leis/L9478.htm.

. Brazilian Legislation, 1999. Lei no. 9.784/99. [Brazilian Administrative Procedure Act] Available at: http://www.planalto.gov.br/ccivil_03/leis/L9784.htm

. Brazilian Legislation, 2010, a. Available at http://www.planalto.gov. br/ccivil_03/_Ato2007-2010/2010/Lei/L12351.htm

Brazilian Legislation, 2010, b. Available at http://www.planalto.gov. br/ccivil_03/_Ato2007-2010/2010/Lei/L12304.htm

Brazilian Legislation, 2010, c. Available at http://www.planalto.gov. br/ccivil_03/_ato2007-2010/2010/Lei/L12276.htm

Brazilian Legislation, 2012, d. Available at http://www.planalto. gov.br/ccivil_03/_Ato2011-2014/2012/Lei/L12734.htm.

. New Reserves, 2013, a. Available at http://www.brasil.gov.br/energia-en/pre-salt/new-reserves

. Pre-salt Wealth, 2013, b. Available at http://www.brasil.gov.br/ energia-en/pre-salt/pre-salt-wealth.

BINENBOJM, Gustavo. As agências reguladoras independentes e a democracia no Brasil [The Independent Agencies and democracy in Brazil]. 3 Revista Eletrônica do Direito Administrativo e Econômico. 1 (2005) http://www.direitodoestado.com/revista/REDAE-3-AGOSTO-2005-GUSTAVO\%20BINENBOJM.pdf

CHEVRON, 2012. Frade response. Available at http://www.chevron. com/Fraderesponse/.

For 2012, http://www.acinh.com.br/cotacao.asp.

CONGRESSO NACIONAL, 1995. Diário do Congresso Nacional [Journal of Federal Congress], available at http://www.stf.jus.br/arquivo/biblioteca/pec/EmendasConstitucionais/EC9/Camara/EC009_ cam_20021995_ini.pdf

ESTĀDO DE SÃO PAULO, 9 de outubro de 1975, [Newspaper: State of San Paulo] available at http://memoria.petrobras.com.br/acervo/contratos-de-risco-para-explorar-petroleo1\#.UH2YO2-aVvo.

ENERST \& YOUNG TERCO. Doing Business in Brazil, 2011. Available at http://www.ey.com/Publication/vwLUAssets/Doing_business_in_ Brazil_2011/\$FILE/Doing\%20Business\%20in\%20Brazil\%202011.pdfIEA, 2012. World Energy Outlook, at 76.

FOLHA DE SÃO PAULO, 2013. Primeiro leilão do pré-sal vai ocorrer em novembro, diz ministério. Available at http://www1.folha.uol.com. br/mercado/1219323-primeiro-leilao-do-pre-sal-vai-ocorrer-em-novembro-diz-ministerio.shtml

IBP - Instituto Brasileiro de Petróleo [Brazilian Petroleum Institute], 2013. Modelos de Contrato. Available at http://www.ibp.org.br/main. asp? Team $=\% 7 B F 400 B B 19-A B 8 B-4 D D 4-97 F 0-006 C 250 A 46 C 3 \% 7 D$ LUCCHESI. Celso Fernando. Petróleo. 12 Estudos Avançados (online) 17, 28-9 (1998). Available at http://www.scielo.br/pdf/ea/v12n33/ 
v12n33a03.pdf.

MACALINN, Gerald Paul; ROSEN, Dan, STERN John P. An introduction to American Law 385. Carolina Academic Press, 2nd ed. 2005.

PEDROSO JR, Jorge Antônio. A Atuação Transnacional das National Oil Companies [The Transnacional Performance of the National Oil Companies], in Novos Rumos do Direito do Petróleo [New Directions for Oil and Gas Law] (Renovar, 1st ed. 2009).

PETROBRAS. The world's largest capitalization, 2010. Available at http://www.petrobras.com.br/rs2010/en/relatorio-de-sustentabilidade/ atuacao-corporativa/estrategia/a-maior-capitalizacao-do-mundo/index.asp

. Governance. Capital Ownership, 2012. Available at http://www.investidorpetrobras.com.br/en/governance/capital-ownership/

SMITH, Ernest E., et al. International Petroleum Transactions, Third Edition (Rocky Mountain Law Foundation 2010)

SOUSA, Francisco José Rocha de. A cessão onerosa de áreas do pré-sal e a capitalização da PETROBRÁS [The Onerous Assignment and Petrobras's capitalization]. Available at:

http://www2.camara.leg.br/documentos-e-pesquisa/publicacoes/estnottec/tema16/2011_907.pdf

QUEIROZ GALVÃO. Relação com os investidores, 2013. http://ri.qgep. com.br/queirozgalvao/web/mobile/conteudo_mobile.asp?idioma=0\&conta $=28 \&$ tipo $=33940 \#$.

SERRA, Rodrigo Valente. Distribuição das Rendas Petrolíferas no Brasil: uma sistematização crítica das alternativas em debate nas casas legislativas nacionais, 2013. Available at http://www.uff.br/macaeimpacto/ OFICINAMACAE/pdf/13_RodrigoSerra.pdf

SILVA, Carla Alves Paulo. Production sharing contracts and concessions in the Brazilian subsalt region. 2012. Available at: https://www. duo.uio.no/handle/123456789/22787? show=full

STF. ADI 4492 - Ação direta de inconstitucionalidade, 2012, a. Available at http://www.stf.jus.br/portal/processo/verProcessoAndamento. asp? incidente $=3985062$

Parlamentares ajuizam mandados de segurança sobre royalties, 2012, b. Available at http://www.stf.jus.br/portal/cms/verNoticiaDetalhe.asp?idConteudo $=226549$

. , Medida Cautelar em Mandado de Segurança 31.816 Distrito

Federal, 2013. Available at http://www.stf.jus.br/portal/processo/verProcessoPeca.asp?id=117029164\&tipoApp=.pdf

USA. Constitution of The United States, 1787. Available at: http://www. usconstitution.net/const.pdf

ZACOUR, Claudia; PEREIRA, Tatiana Zuma; CRISTOFARO, Angela Lima Rocha; FRANCISCO, Felipe Ferreira, Petrobras And The New Regulatory Framework For The Activities Of Exploration And Production 
Panorama of Brazilian Law. Vol 1, No 1 (2013)

Of Oil And Natural Gas In The Brazilian Pre-Salt, in 5 Journal of World Energy Law \& Business 125, 2012.

\section{SUPPLEMENTARY MAP}

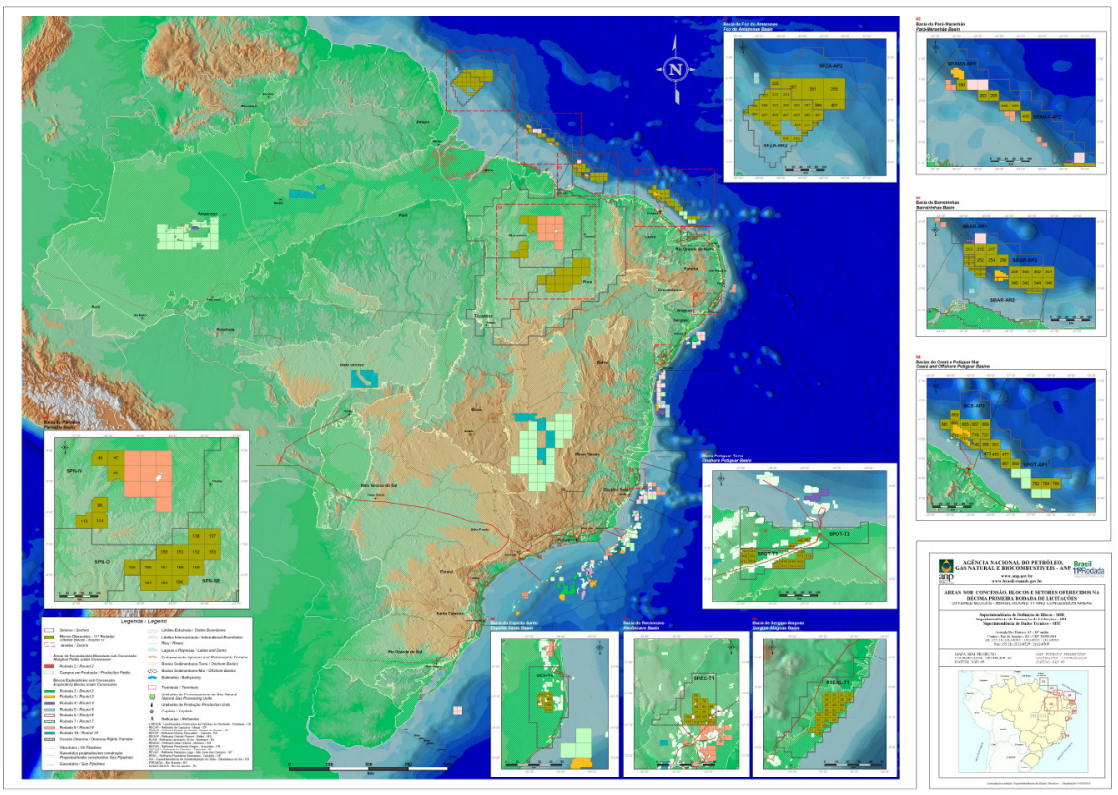

